\title{
EPIDEMIOLOGICAL SURVEY OF ENTEROVIRAL MENINGITIS IN CHILDREN YOUNGER THAN 14 YEARS IN AHVAZ
}

\author{
Amir Sohrabi ${ }^{1}$, Ali Reza Samarbafzadeh ${ }^{1}$, Manoochehr Makvandi ${ }^{1}$, Ahmad Shamsizadeh ${ }^{2}$, Mahmood \\ Shamsi Shahrabadi ${ }^{3}$ \\ 1. Department of Medical Virology, Ahvaz Jondishapour University of Medical Sciences, Iran \\ 2. Aboozar Hospital Pediatric Ward, Ahvaz Jondishapour University of Medical Sciences, Iran \\ 3. Department of Medical Virology, Iran University of Medical Sciences
}

\begin{abstract}
Aseptic meningitis is one of the most common infections of central nervous system. More than $\mathbf{8 0} \%$ of all cases of aseptic meningitis are estimated to be caused by enteroviruses. In our cross-sectional study, enteroviral meningitis was assessed in children younger than 14 years hospitalized with the diagnosis of aseptic meningitis in the pediatric infectious ward of Ahvaz Abozar hospital, Iran, from November 2004 to November 2005. We ascertained of enteroviral meningitis of 57 CSF samples (35 males and 22 females) by RT-PCR and HeLa cell culture. of the 57 CSF samples tested by RTPCR, 30 samples (52.63\%) were positive for enteroviruses and of the 35 CSF samples inoculated on HeLa cells, 10 specimens (28.57\%) were positive for enteroviruses. The average age of 30 children with positive results for enteroviruses was 3 years. The rate of enteroviral meningitis in the males was higher than in females $(56.7 \%$ versus $43.3 \%$ respectively) but there was no significant statistical difference between males and females $(p>0.05)$. The highest incidence of enteroviral meningitis was determined in autumn (47\%) but we couldn't detect any enteroviral meningitis during the summer. Finding of this study represents enteroviral meningitis is the most common cause of aseptic meningitis in Ahvaz city. Early diagnosis and understanding of the role of viruses in aseptic meningitis will help physicians to manage the patients suffering from aseptic meningitis and planning for prevention of this syndrome.
\end{abstract}

Keywords: • Enteroviral meningitis • CSF • RT-PCR • Ahvaz

\section{Introduction}

$\mathrm{E}$ nteroviruses comprise a large genus belonging to the picornaviridae and show similar morphological, structural and molecular properties and replication strategies. Sixty-six immunological distinct serotypes are known to circulate world wide and to cause infections in humans $(1,2)$. They are classified according to their antigenic properties as coxsackieviruses groups $\mathrm{A}$ and $\mathrm{B}$, echoviruses, polioviruses, and enteroviruses type 68-71 $(3,4)$. Enteroviruses are responsible for significant and frequent human illness, ranging from mild to severe disease, including meningoencephalitis, myocarditis, paralysis, and even death (5). More

Corresponding author: Amir Sohrabi: Department of Medical Virology, Ahvaz Jondishapour University of Medical Sciences, Iran, Tel: +98-021-55355249

E-mail : sohrabi_amir@walla.com than $80 \%$ of all cases of aseptic meningitis worldwide are estimated to be caused by enteroviruses. Children frequently develop enteroviral meningitis especially during the summer and autumn, which leads to more hospitalization in most of the patients $(6,7)$. There is currently no specific treatment of enterovirus infections, although treatment of older children and adults with pleconaril, a novel anti picornaviral compound, has been associated with reduced severity and duration of symptoms $(8,9)$. Studies on the molecular epidemiology of enteroviruses have focused on the evolutionary inference derived from the comparison of virus isolates

within a serotype over time, as well as comparison of isolates from different serotypes and even between different genera within the Picornaviridae. The traditional procedure for enterovirus identification known as neutralization test is generally reliable, poses a number of draw backs. 
It is labor-intensive, time-consuming and may fail due to antigenic drift, recombination, or the presence of virus mixtures. The modern molecular biology technology uses the reverse transcriptasepolymerase chain reaction (RT-PCR) for rapid diagnosis of enterovirus infection minimizing the requirement for isolating enteroviruses in culture for most common diagnostic and epidemiological applications $(10,11)$. The epidemiology of pediatric enterovirus infections in many regions of Iran is still unknown. In the present cross-sectional study, we conducted a 1 year research to determine the prevalence of enteroviral meningitis in children with aseptic meningitis. RT-PCR and HeLa cell culture of CSF for enterovirus detection were systematically performed.

\section{Materials and Methods}

\section{Patient samples}

From November 2004 to November 2005 a total 57 ( 35 males and 22 females) children younger than 14 years, hospitalized in the pediatric infectious ward with the diagnosis of aseptic meningitis in Abozar hospital of Ahvaz, Iran. The preliminary diagnosis of aseptic meningitis was based on ; ( a) clinical symptoms indicative of meningitis (fever, headache, and neck stiffness), (b) pleositosis ( $>5$ white blood cells $/ \mathrm{mm}^{3}$ ) in CSF, and (c) the lack of an alternative diagnosis (i.e. negative culture for bacteria and fungi). Complete clinical data were gathered from patient's medical records. Then CSF specimens were collected and transported by cool box to virology laboratory of Ahvaz medical faculty and stored at $-70^{\circ} \mathrm{C}$ until experiment.

\section{Cell culture}

Due to lack of cell lines and large number of CSF samples, we only could culture 35 CSF samples in HeLa cells. HeLa cells were grown in Dulbecco's modified eagle medium (Himedia , India) supplemented with $10 \%$ fetal calf serum ( Gibco , UK) , $100 \mathrm{u} / \mathrm{ml}$ of penicillin , $100 \mu \mathrm{g} / \mathrm{ml}$ of streptomycin, and $5 \mu \mathrm{g} / \mathrm{ml}$ of amphotericin B . A minimum of $100 \mu \mathrm{l}$ of each CSF specimen was inoculated into monolayers of HeLa cells in 24 well plates containing DMEM supplemented with $2 \%$ fetal calf serum, Infected cells were incubated at $37^{\circ} \mathrm{C}$ in an atmosphere containing $5 \% \mathrm{CO}_{2}$. The cells were observed daily for 10 to 14 days for cytopathic effect characteristic for enteroviruses. CPE of positive specimens were observable within 2-7 days (Fig.1).

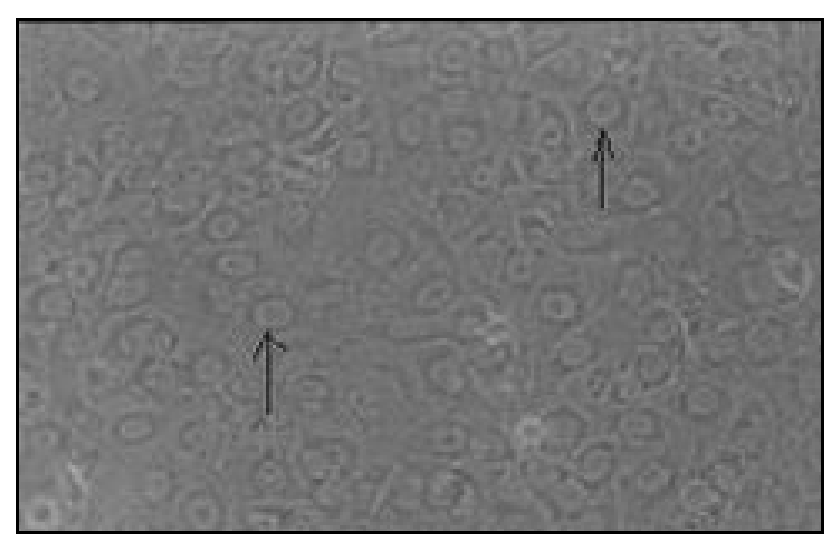

Fig. 1. Positive CSF sample

\section{Extraction of viral RNA}

Viral RNA from $200 \mu 1$ of CSF was extracted using the High pure viral nucleic acid kit (Roche, Germany), according to the manufacture instruction. RNA of sabin polio vaccine was extracted to be used as positive control in RT-PCR.

\section{RT-PCR}

For cDNA preparation all extracted RNA were incubated at $65^{\circ} \mathrm{C}$ for $10 \mathrm{~min}$ then put on ice for 3 min. Briefly, the synthesis of cDNA was performed in a $20 \mu 1$ reaction volume containing 4 $\mu 1$ Expand RT buffer (Roche) , $2 \mu 1100 \mathrm{mM}$ dithiothreitol (DTT) (Roche) , $2 \mu 1 \quad 10 \mathrm{mM}$ deoxynucleoside triphosphate mixture (dNTPs) (Roche), $0.5 \mu 140 \mathrm{u} / \mu 1$ RNase inhibitor protector (Roche) , $0.2 \quad \mu \mathrm{l} \quad 50 \quad \mathrm{u} / \mu \mathrm{l}$ Expand reverse transcriptase (Roche) , $1 \mu 150 \mu \mathrm{m}$ of antisense primer and $5.5 \mu \mathrm{l}$ of a solution with extracted RNA . The mixture was incubated at $42^{\circ} \mathrm{C}$ for 60 min. After elongation, the tubes were inactived at $95^{\circ} \mathrm{C}$ for $6 \mathrm{~min}$. The PCR amplification was carried out in a $25 \mu 1$ reaction volume containing $2.5 \mu 1$ 10x PCR buffer (Roche), $0.5 \mu 1 \quad 10 \mathrm{mM}$ deoxynucleoside triphosphate mixture (dNTPs) (Roche), $0.25 \mu \mathrm{l} 50 \mu \mathrm{m}$ of sense primer; 5'GGCCCCTGAATGCGGCTAAT-3', $0.25 \mu 150 \mu \mathrm{m}$ antisense primer; 5'ATTGTCACCATAAGCAGCCA-3' (TIB Molbiol, Germany), $0.2 \mu \mathrm{l}$ Taq DNA polymerase $(5 \mathrm{u} / \mu \mathrm{l})$ (Roche), and $10 \mu 1$ of the cDNA product. This reaction mixture was amplified for 35 cycles in a programmable thermal cycler (Techne, UK) using the following conditions: $94^{\circ} \mathrm{C}$ for $30 \mathrm{~s}, 60^{\circ} \mathrm{C}$ for $30 \mathrm{~s}$, and $72^{\circ} \mathrm{C}$ for $30 \mathrm{~s}$, plus a final extension period at $72^{\circ} \mathrm{C}$ for $7 \mathrm{~min}$. The RT-PCR products were analyzed by electrophoresis on a $2 \%$ agarose gel containing ethidium bromide (Roche), and 
were visualized under ultraviolet light. The 100-bp DNA ladder (Roche) was used as a size marker to estimate the length of products. A positive RTPCR reaction was expected to produce a 144-bp band (Fig. 2) $(12,13,14)$.

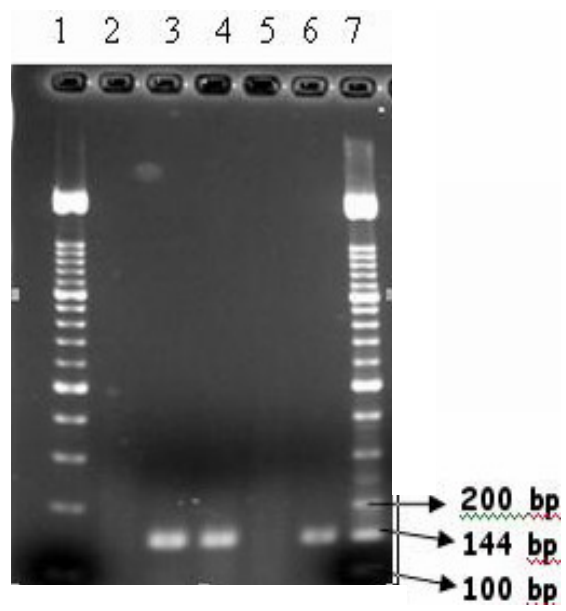

Fig. 2. Agarose gel electrophoresis $(2 \%)$ following RT-PCR of CSFs for enteroviruses. Tracks 1 and 7 show 100 bp DNA ladder. Line 2 indicates negative control. Line 3 belongs to positive control (sabin vaccine). Line 4 and 6 indicate 2 positive CSF samples, and line 5 demonstrates a negative CSF sample result.

\section{Results}

Of the 57 CSF samples tested by RT-PCR, 30 CSF samples $(52.63 \%)$ were positive for enteroviruses and of the $35 \mathrm{CSF}$ samples inoculated on HeLa cells, $10 \mathrm{CSF}(28.57 \%)$ were positive for enteroviruses, most of the CPEs were observed within 2-7 days. The average age of children with positive results for enteroviruses was 3 years. The rate of enteroviral meningitis in males was higher than in females $(56.7 \%$ versus $43.3 \%$ respectively) but this difference was not statisticaly significont (by SPSS software version11.5, Chisquare test; $p>0.05)$. The incidence of enteroviral meningitis was in autumn (47\%), winter (30\%), and in spring (23\%), but we couldn't detect any enteroviral meningitis during the summer. Thirty enterovirus positive CSF samples $(52.63 \%)$ had a median of 193 white blood cells $/ \mathrm{mm}^{3}$ (ranged between, 5 to 1480), $83 \%$ lymphocyte and $17 \%$ neutrophil. Median level of CSF protein and glucose were $41.9 \mathrm{mg} / \mathrm{dl}$ and $67.5 \mathrm{mg} / \mathrm{dl}$ respectively. Out of 30 positive cases of CSF samples for enteroviral meningitis, $(73.4 \%)$ had a clear appearance and $3(10 \%)$ were semi turbid.

\section{Discussion}

This epidemiological study is the first study of enteroviral meningitis in the city of in Ahvaz, Iran. Encephalitis and meningitis cases frequently occurr in Iran, but there are few reports indicating the prevalence of aseptic meningitis in this country. Since, enteroviruses are the most common cause of aseptic meningitis. There are several factors affecting epidemiology of these viruses, including sex, age, seasonality, geographic area, environmental - hygienic, socio-economical conditions, etc. The data collected from various parts of the world implies the different impacts of these viruses as an etiology of aseptic meningitis. In this study, enteroviruses were detected by RT-PCR in $52.63 \%$ of children younger than 14 years suffering from aseptic meningitis. According to researches conducted in Tehran, Iran, the prevalence of enteroviral meningitis was $15 \%(15,16)$, but prevalence of enteroviral meningitis in some area like Tunisia and Turkey has been reported to be higher than our results ( $71 \%$ and $63 \%$ respectively) $(2,17)$. This discordance between prevalence of enteroviral meningitis in Tehran and Ahvaz can be attributed to poor hygienic practice in the population is some residential area in Ahwaz, and the majority of the patients referred to the hospital because of aseptic meningitis belonged to poor parts of the city. Therefore the higher prevalence of enteroviral meningitis in Ahvaz in compare to Tehran isprobably due to higher sanitation in the latter. In this study it was found that enteroviral meningitis is more prevalent in males than females, like other studies reported by researchers $(18,19)$. Seasonal variation of enteroviral meningitis in different studies from various regions has been observed $(20,21)$. The peak of enteroviral meningitis was in autumn and winter but we couldn't detect any case of enteroviral meningitis in summer. In the summer, Ahvaz is very warm $\left(43-50^{\circ} \mathrm{C}\right)$, probably this degree of warmth is not in favor of enterovirus survival. On the contrary, Ahvaz has a mild fall and winter climate. Therefore, the peak of detection of enteroviruses in these seasons in Ahvaz was not surprising. All the measured indexes of CSF samples in the patients were normal similar to the CSFs indexes reported by other researches (22). Early diagnosis of aseptic meningitis will help physicians for better management of the patients suffering from this illness. Besides, the data will help better understanding of the role of viruses in 
aseptic meningitis and planning for prevention of central nervous system infection. Due to lack of adequate equipments and insufficisent financial support we could not type the isolates of enteroviruse and further studie are rquired for complete identification of there agents. Couldn't typing of enteroviruses, it is hoped that to prove to be true in future.

\section{Acknowledgments}

We are indebted to Mishar Klishadi for helping us in cell culture and RT-PCR. We are grateful to laboratory workers and nurses of Ahvaz Abozar hospital for gathering CSF samples. This study was financially supported by deputy of research of Ahvaz Jondi Shapour University of Medical Sciences.

\section{References}

1 Muir, P.,U. Kammerer., K. Korn., N.M. Mulders ., T. Poyry., B.Weissbrich and et al; 1998; Molecular typing of enteroviruses: Current status \& future requirements.J. Clin Microbiol Rev 11(1):202-27.

2 Gharbi, J., H. Jaidane ., B.M. M'hadheb .,E.R. Hiar ., C. Chouchene ., N.M. Gueddiche and et al; 2006; Epidemiological study of non-polio enteroviruses neurological infections in children in the region of Monastir, Tunisia.J. Diag Microbiol Infect Dis 54:3136.

3 Oberste, M.S., K. Maher and M.R. Flemister ; 2000; Comparison of classic and molecular approaches for the identification of untypeable enteroviruses.J. Clin Microbiol 38:1170-74.

4 Ishiko, H., Y. Shimamda ., M. Yonaha ., O. Hashimoto ., A. Hayashi ., K. Sakae and et al; 2002; Molecular diagnosis of human enteroviruses by phylogenybaseclassification by use of the vp4 sequence. J.Infect Dis 185: $744-54$.

5 Melnic, J.L; 1996; Enteroviruses: Polioviruses, coxsackieviruses, echoviruses, and newer enteroviruses. In: Fields Virology. Vol. 1, Fields, knipe, Howley, Chanock, Melnick, Monath and et al ed., LippincottRaven, Philadelphia pp: 655-712.

6 Modlin, J.F;1997; Update on enterovirus infections in infants and children.J. Adv Pediatr Infect Dis 12:155-80.

7 Vokshoor, A., L. Moore; 2004; Viral Meningitis [code available at http://www.emedicine.com/ neuro/ Topic607.htm].

8 Abzug, M.J., G. Cloud ., J. Bradley., P.J. Sanchez., J. Romero., D.Powell and et al; 2003; Double blind placebo-controlled trial of pleconaril in infants with enterovirus meningitis. J. Pediatr Infect Dis 22:335-41.

9 Tormey, V.J., J.R. Buscombe., M.A. Johnson., A.P. Thomson and A.D Webster; 2003; Spect scans for monitoring response to pleconaril therapy in chronic enteroviral meningoencephalitis.J. Infect 46:138-40.

10 Georgopoulou, A., P. Markoulatos ., N. Spyrou ., N. Vakalis.,T.A. Bei and N.C. Vamvakopoulos ; 2001; High sequence divergence in the $5^{\prime}$ non coding region of reference coxsackie $\mathrm{B}$ and echo viral strains and clinical isolates revealed by restriction fragment length polymorphism analysis.J. Mol Cell Probes 15:317-27.

11 Gorgievski, H.M., J.D. Schumacher and N. Vilimonovic; 1998; Detection by PCRof enteroviruses in cerebrospinal fluid during a summer outbreak of aseptic meningitis in Switzerland.J. Clin Microbiol 2408-12.

12 Zoll, J.G., G.J.W. Melchers., H. Kopecka., G. Jambroes., D.V.A.J.H. Poel and D.M.J. Galama; 1992; General primer-mediated polymerase chain reaction for detection of enteroviruses: Application for diagnosticRoutine and persistent infections.J. Clin Microbiol 30(1):160-65.

13 Monpoecho, S., A. Maul ., C.B. Mignotte., L. Schwartzbrod., S. Billaudel and V. Ferre; 2001; Best viral elution method available for quantification of enteroviruses in sludge by both cell culture and reverse transcriptase- PCR.J. Applied and Environmental Microbiol 67(6):2484-88.

14 Samalling, W.T., E.S.Sefers., H.Li and W.Y. Tang; 2002; Molecular approaches to detecting herpes simplex virus and enteroviruses in the central nervous system. J.Clin Microbiol 40(7):2317-22.

15 Modarres, S., S. Modarres and M. Ghofrani; 1997; Acute aseptic meningitis and encephalitis with viral etiology in children from Tehran. J. Irn Med Sci 22(3\&4):98.

16 Sarijloo, M and R.Nategh ; 2001; Determination of the role of enteroviruses in meningitis and meningoencephalitis in the patients referred to different hospitals by RT-PCR in Tehran [dissertation]. Univ, Tehran pp: 79-83.

17 Guney, C., E.Ozkaya., M. Yapar ., I. Gumus., A. Kubar and Doganci L; 2003; Laboratory diagnosis of enteroviral infections of the central nervous system by using a nested RT-polymerase chain reaction (PCR) assay.J. Diag Microbiol Infect Dis 47:557-62.

18 Grist, N.R., E.J. Bell and F. Assad ;1978 ; Enteroviruses in human disease.J. Prog Med Virol 24:11457.

19 Dua, P; 2003; Enteroviruses [code available at http://www.emedicine.com/med/topic681.htm].

20 Dagan, R; 1996; Non polio-enteroviruses and the febrile young infant: Epidemiologic, clinical and diagnostic aspects.J. Pediatr Infect Dis 15:67-68.

21 VerboonMaciolek, M.A.,T.G. Krediet., A.M. Vanloon ., J.A.Kaan., J.M.D. Galama., L.J. Gerards and et al; 2002; Epidemiological survey of neonatal non-polio enteroviruses infection in the Netherlands.J. Med Virol 66:241-45.

22 Seehusen ,A.D., M.M. Reeves and A.D. Fomin; 2003; Cerebrospinal fluid analysis.J. Am Fam Phy 68(6):1103-08. 